\title{
International Financial Governance: The Role of the BRIC Countries Changjiang $\mathrm{Yu}{ }^{1, a}$

\author{
${ }^{1}$ Shangrao Vocational Technical College, Shangrao, Jiangxi, P.R.C ; Lyceum of the philippines \\ university bantangas \\ a207593@qq.com
}

\begin{abstract}
Keywords: BRICS countries; Global governance; International financial governance; Capacity cooperation
\end{abstract}

\begin{abstract}
The BRICS countries represent the emerging economies that have attracted the most attention in the development of the world today. Since the establishment of the BRICS cooperation mechanism, finance has been one of the most prominent areas of cooperation. With the vigorous promotion by the BRICS, the BRICS New Development Bank has been put into operation. The BRICS foreign exchange reserve pool has also been set up. The BRICS countries have the basic conditions that affect the structure of international financial governance. Starting with the dilemma of international financial governance and the role of BRICS countries, this paper analyzes the international financial situation and the constraints faced by BRICS countries from the perspectives of the international monetary system and the discourse power of international financial institutions. After reviewing the achievement of the cooperation in the financial field since the establishment of cooperative mechanism of the BRICS countries, a breakthrough point has been put forward to further strengthen financial cooperation for the future. In the future, BRICS countries can coordinate their monetary policies to cope with the impact of international capital flows and make use of new concepts such as green finance for project financing, promoting the capacity cooperation among countries through financial cooperation at the same time.
\end{abstract}

\section{"Breakthrough": Plight of International Financial Governance and BRICS Countries}

The global financial crisis has highlighted the growing economic and financial dependence of all countries in the world. It was against this background that all governments, international organizations and international non-governmental organizations must coordinate and cooperate in international financial affairs and formulate relevant norms and standards. International financial governance refers to the process by which sovereign states and their extended forces, such as intergovernmental financial regulators and international financial organizations, multilateral, formal or informal coordination, cooperation and consensus-building to participate in the management of global financial affairs and take joint actions or measures aimed at establishing or maintaining a desired international financial order. International financial governance refers to the joint action or measures of sovereign states and their extended powers (such as intergovernmental financial regulators and international financial organizations) in the management of global financial affairs through bilateral, multilateral, formal or informal coordination, cooperation and consensus-building to develop or maintain the desired international financial order. Financial governance includes the international monetary system, international financial institutions, international financial regulation and international financial infrastructure. Efficiency and security are two core goals of international financial governance. The current international financial governance mechanism is based on the Bretton Woods system after World War II, although which collapsed in the 1970s, the ensuing Jamaican system strengthened the centrality of the dollar and continued the international financial order. Based on this, the international financial governance includes two aspects. One is to establish a cooperation mechanism to enhance the efficiency of international financial operations, the other is to provide institutionalized security for the development of international financial activities.

\section{The US Dollar Center and the International Monetary System}

The international monetary system is an important institutional arrangement for adjusting international monetary relations and a key medium for coordinating international financial policies 
and promoting the sound development of international economic and trade activities. After the breakout of global financial crisis, the reform of the international monetary system has become one of the core issues of global economic governance. The current main body of the international financial order is still based on what was formed after the Second World War, in which IMF is one of the pillars of the international financial order. However, its institutional arrangement aims at safeguarding the interests of developed western countries headed by the United States. In recent years, with emerging economies rising in groups, the BRICS have played an increasingly prominent role in the world's economy and finance. They have put forward a series of demands for reforming the international monetary system and international financial institutions.

Although the Jamaica system has realized the diversification of the international reserve currency supply and broken the dominance of the U.S. dollar, and the international currency has been supplemented by various currencies such as the euro and the yen, the US dollar, which has more than $60 \%$ of proportions in the global foreign exchange reserves remains the absolute leader in the international reserves of various countries. However, given the inherent deficiencies of the single reserve currency, it's difficult to overcome the "Triffin challenge". As the foreign exchange reserve currency of many countries and the settlement currency of international commodity trade, the US dollar can hardly overcome the challenge that is to maintain its reserve status requires that the U.S. dollar maintain its long-term stability and maintain its long-term trade surplus, while as a reserve currency it's required to have flow

Dynamic, resulting in a sustained trade deficit. At present, world trade and the global economic operation rely heavily on the U.S. dollar, but it is hard to find a new world currency to replace the U.S. dollar, which has to be held by all countries in the world even in the aftermath of the international financial crisis or the devaluation of the U.S. dollars. The global financial crisis is the first financial crisis that took place in the core economies of the world after the disintegration of Bretton Woods system. However, due to that the establishment of the international economic system is based on the U.S. dollar-centric international monetary system, the United States can shift the crisis outwards by manipulating the U.S. dollar. making the emerging economies pay for U.S. monetary policy and become indirect victims of the global financial crisis.

The reform of the international monetary system should meet at least three objectives. Firstly, to better protect the financial stability and security of emerging economies. Secondly, to diversify the reserve currencies so as to reduce the dependence on a single currency. Thirdly, the international financial and monetary policies should be more coordinated. The goal of the future reform of the international monetary system should be establishing a binding sovereign monetary system or some kind of super-sovereign monetary system.

\section{The Discourse Power of International Financial Institutions}

International financial institutions are the institutionalized products and the practitioners of global economic governance. The "Post-2015 Agenda for Sustainable Development" of the United Nations emphasizes that adopting integrated policy instruments in the development agenda to ensure inclusive economic development, inclusive social development and environmentally sustainable development, which requires that resources and funds be efficiently deployed globally. As the most important coordinator of global financial resources, international financial institutions need to change their logic to place more emphasis on social and environmental standards above economic standards, promoting the realization of inclusive development. The multilateral financial institutions represented by the International Monetary Fund have played a positive role in helping emerging economies to develop their economies and improve their infrastructure. However, since the vast majority of international financial institutions are under the control of a few developed countries, which is contrary to their original purpose of establishment. There are often many harsh conditions accompanied with financial support to emerging economies, including the BRICS countries.

The main contents of the reform of international financial institutions are to reform the mechanism of decision-making at international financial institutions, enhance the discourse power of emerging economies, establish an early-warning system of crisis-oriented global coverage as 
soon as possible, and improve the internal governance structure of international financial institutions. At the same time, a timely, efficient and equal crisis rescue mechanism is needed to be established to enhance the ability of the international financial institutions to effectively fulfill their duties.

In 2008, the IMF conducted a reform that aimed to increase the basic voting rights to 750 while keeping the ratio of basic voting rights to total voting rights at around 5.5\%, and maintaining the number and proportion through effective mechanisms fixed. However, the proportion of the basic voting rights in the total voting rights also depends on other factors and therefore may not necessarily safeguard the interests of the "weak countries". In addition, the proportion of 5.5\% of the basic voting rights in the actual voting is too small, and was also distributed to both developed and developing countries, so voting can not be inclined to developing countries. The reform of the basic voting rights has almost no effect.

In 2010, the IMF reintroduced the reform of share and voting rights, the emerging economies gained a higher share and voting rights (Table 1), which marks the beginning of the reconstruction of the international monetary system and the weakened institutional foundation of the U.S. dollar. However, since the GDP weight in current share formula of IMF is only 50\%, the emerging economies have taken a share lower than their share of total economy.

Table 1 IMF Share and Voting Rights before and after the Reform

\begin{tabular}{|l|l|l|l|l|l|}
\hline Time & \multirow{2}{*}{$\begin{array}{l}\text { Before or } \\
\text { after } \\
\text { Reform }\end{array}$} & \multicolumn{2}{|l|}{ Share Ratio(\%) } & \multicolumn{2}{l|}{ Voting Rights Ratio(\%) } \\
\cline { 3 - 6 } & G7 & BRICS & G7 & BRICS \\
\hline \multirow{2}{*}{2008} & Before & 42.5 & 10.6 & 43.0 & 10.4 \\
\cline { 2 - 6 } & After & 45.3 & 11.5 & 43.0 & 11.0 \\
\hline \multirow{2}{*}{2010} & Before & 45.3 & 11.5 & 43.0 & 11.0 \\
\cline { 2 - 6 } & After & 43.4 & 14.8 & 41.2 & 14.1 \\
\hline
\end{tabular}

Source: IMF, Finance Department, July 2011

\section{"Turning the Virtual into Reality", the Financial Cooperation Results of BRICS}

In 2008, at the meeting of finance ministers held in Brazil, the BRIC countries first called for the reform of the international financial system to enable it to correctly reflect the new changes in the world economy. Since 2010, the BRICS countries have coordinated their efforts in reducing their dependence on the U.S. dollar and promoting the diversification of the international monetary system. The financial and monetary cooperation has continuously deepened, which included advocating a wide range of monetary systems, strengthening regional monetary cooperation, promoting currency swaps and settlement of local currency trade, boosting the status of SDRs, and establishing development financial institutions.

Firstly, the BRICS countries jointly promote the reform of international financial institutions. With the continuous appeals of emerging economies represented by the BRICS countries, the reform of share and voting rights by the IMF in 2008 and 2010 was promoted. In 2012, BRICS countries collectively raised their funds to the IMF, raising a total of 75 billion U.S. dollars.

In April 2015, the World Bank adopted its shareholding reform program. China's voting rights at the World Bank increased from $2.77 \%$ to $4.42 \%$. Its voting power rose from the sixth to the third, while the United States remained the share of the World Bank Most countries. In January 2016, the program of reforming the shareholding of the International Monetary Fund in 2010 officially came into force. China, Brazil, India and Russia entered the top ten shareholders, with a total share of $14.7 \%$, but not yet reached $15 \%$ of the share of the shareholding, with which they can have the veto power. Both of these reforms should have been completed in 2011 but due to the passage of the program by the United States Congress in December 2015, the program of the IMF equity share reform was delayed for five years, during which the world economy has undergone tremendous 
changes. The emerging economies have seen a rise in the global economy. However, the shareholding of international financial institutions has not faithfully reflected the economic power of the countries concerned. The share of the emerging powers in their shareholdings is still lower than what it should be according to their total economic. In addition, the RMB's approval to join the SDR currency basket in 2015 is another important component of restructuring the international monetary system. Although the U.S. dollar's weight in the currency basket has only dropped from $41.9 \%$ to $41.73 \%$, the RMB has gained $10.92 \%$ of its weight, which will better support the internationalization of the RMB.

Secondly, BRICS countries build multilateral financial institutions to supply global public goods. In 2013, at the fifth BRIC summit, the five nations unanimously decided to set up a development bank and a foreign exchange reserve pool. In 2014, the BRICS signed an agreement in Fortaleza, Brazil to set up the development bank and establish emergency reserve arrangements of BRICS. The BRICS New Development Bank is an initial attempt made by the BRICS countries about development finance after their repeated efforts to promote the reform of international financial governance with little effects. It has broken the monopoly of international financial organizations in the western countries and raised the discourse power of the BRICS countries in the field of international financial governance. At the same time, it has positive significance for strengthening international financial stability. In July 2015, the BRICS New Development Bank officially opened and settled in Shanghai. In April 2016, the BRICS New Development Bank completed the first batch of loans of US \$ 811 million to support four green renewable energy projects in Brazil, China, India and South Africa respectively, keeping the aim of supporting for infrastructure construction and promoting the purpose of sustainable development.

The establishment of BRICS emergency reserves helps to improve the financial stability and security in BRICS countries. It not only helps member countries to cope with short-term liquidity problems, but also reduces the impact of external shocks on the BRICS economies. In addition, the BRICS emergency reserve arrangement also reduces the dependence of the BRICS countries on the IMF and the World Bank, which can help the BRICS countries to increase their discourse power in the international governance system and build a new international financial order. The solution to the liquidity problems in the BRICS countries can not only avoid the competitive devaluation, but also save foreign exchange reserves and reduce the global imbalances.

Thirdly, BRICS countries promote currency swap and domestic currency settlement and carry out securities market cooperation. BRICS countries promote mutual exchange of information among member countries in economic and financial fields and project financing through currency swap and domestic currency settlement to deepen all-round cooperation.

China and Russia took the lead in carrying out the mutual listing of RMB and Ruble in 2010. In 2011, they signed another bilateral settlement agreement to extend the scope of domestic currency settlement to general trade. China signed domestic currency swap agreements of RMB190 billion, RMB150 billion and RMB30 billion respectively with Brazil, Russia and South Africa in 2013, 2014 and 2015. At the same time, the BRICS nations also introduced bilateral bond issuance by introducing investors from other countries to their bond markets, fostered bilateral domestic currency bond markets, optimized the financial system and reduced systemic risk. For example, China and Russia jointly negotiated to push Russia to issue RMB bonds in China.

In October 2011, Brazilian Securities and Futures Exchange, the Moscow Interbank Currency Exchange Exchange, the Bombay Stock Exchange of India, Hong Kong Exchanges and Clearing Limited of China and the Johannesburg Stock Exchange of South Africa established the BRICS Alliance during the International Federation of Stock Exchanges held in South Africa. From March 2012, they started to trade the derivative products of benchmark stock market index each on their own trading platforms to develop new products related to stock market index of BRICS countries and plan to cooperate in developing products and services related to other asset classes. 


\section{"Making Persistent Efforts", the Financial Cooperation Breakthrough of BRICS}

Since the establishment of the cooperation mechanism, the countries of the BRICS have achieved fruitful results in the area of financial cooperation, which is the most prominent part of the BRIC cooperation. The five countries have stepped up their cooperation in such fields as trade, finance and infrastructure construction by actively promoting the Asian Infrastructure Investment Bank, the BRICS New Development Bank and the BRICS Foreign Exchange Reserve. In the future, all countries can make breakthroughs in the areas such as monetary policy coordination, cooperation in financial support and capacity cooperation and green finance, moving towards the goal of a large trade and investment market, a huge monetary and currency circulation, and a large-scale infrastructure.

\section{Monetary Policy Coordination}

The globalization of production has promoted the globalization of trade and finance. The world economies are closely interlinked and their interdependence continues deepened. The spillover effects of economic policies have also been constantly increased. The formulation of the economic policy has been increasingly influenced by the world power and regional power. In terms of monetary policy, financial liberalization has been deepening since the 1990s and the scale of capital flows has been increasing. For example, a series of economic crises erupted in emerging economies in the 1990s. If necessary monetary policy can be carried out by the countries, the negative impact will be much smaller. After the global financial crisis, the major developed economies in Europe and the United States implemented unconventional monetary policies, resulting in excess global liquidity and greater policy spillover effects. Therefore, the coordination of international monetary policy has become important and urgent, especially for emerging economies.

As representatives of emerging economies, the BRICS countries should assume more responsibilities and obligations. At present, the BRICS only reflect on the currency swap in the coordination of monetary policy, but the scale of the swap and the utilization effect are relatively limited. Under the situation of the differentiation of monetary policy in developed countries, BRICS countries should actively coordinate monetary policy by using products such as interest rates and exchange rates, currency swaps, and currency derivatives. At the same time, on the basis of the IMF, they should negotiate and collaborate on the currency and exchange rate issues to prevent competitive currency devaluations. All countries need to actively participate in the formulation of international monetary rules and the construction of the international financial system to gain more discourse power and obtain more economic rights and interests in the formulation of international economic rules.

\section{Production Capacity Cooperation and Financial Support}

The increasing economic power of the BRICS countries and the gradual expansion of the trade scale have created a larger demand for mutual investment and financing. Therefore, more financial institutions, regulators, channels, facilities and services are required. The traditional global value chain is the international cooperation of industrial chain, and the current one is the combination of the industrial chain and the financial chain. Finance provides effective support to production capacity cooperation among BRICS countries in various fields such as capital formation, capital guidance, credit catalysis and risk management through such products as funds, credit and insurance. The establishment of BRICS New Development Banks has set a long-term and developing international financial platform for emerging economies to better meet the needs of growing investment and financing of BRICS countries and promote economic and social development. Developed financial entities can make business and product innovations according to the characteristics of the BRICS markets and make breakthroughs in financing services, export credit and cooperation between BRICS countries and new development banks. Equity, quasi-equity, fund investment and other diversified ways can be used to carry out direct investment.

In the critical period of promoting capacity cooperation among BRICS countries and the adjustment of their respective industrial structures, governments, commercial banks and policy financial institutions can support different industries and sectors in terms of policy choices and support methods. On the one hand, the government exercises macro-control and guides the capital 
investment through the development of appropriate financial policies and industrial policies, the macro-control of commercial credit investment. On the other hand, it will focus on providing some industries with low-cost financial support for effective production docking. For example, differentiated interest rate policies may support some industries and key cooperative enterprises, or banks can be encouraged to provide low interest rate credit support for some key projects and promote capacity cooperation in the form of government financial subsidies. BRICS countries are at a critical juncture in the restructuring of the economy and the transformation of the mode of development. In the meantime, strengthening production capacity cooperation with each other through financial support is an effective way for achieving mutual benefits and win-win results.

\section{Financing Projects and Green Finance}

Green finance refers to financial activities that support the improvement of the environment, the fighting climate change and the improvement of the efficiency of resource utilization. Green financial system refers to a series of policies and institutions that guide social funds into the development of green industry through financial services such as loans, private equity investment, bond issuance and stocks, insurance and carbon finance. In December 2015, driven by China's initiative, the G20 Green Finance Study Group was set up to promote international cooperation in green finance and mobilize more resources to accelerate the green transformation of the global economy. The first loans of the BRICS New Development Bank were used to four green renewable energy projects in Brazil, China, India and South Africa respectively, which reflected the support of BRICS New Development Banks on developing green finance and channeling capital to energy-saving and environmental protection industries. The BRICS Development Bank has developed the principle of green bonds to ensure that proceeds are earmarked to support green projects and ensure green development both in terms of credit and financing. In addition, China and Brazil have already defined green credit at the national level and introduced relevant indicators. As green finance becomes a global consensus, the BRICS countries can further establish a sound green financial system, taking the lead in realizing the opening up of green capital markets among investors in the five countries, and guiding more funds to green industries in various forms and further improve the restraint mechanism to curb the investment in highly polluting industries, which is not only an inevitable trend in the world but also the only way for BRICS countries to achieve sustainable development.

\section{References}

[1] W. Li. The Political Foundation of Currency Competition -- Based on the Study of International Political Economy. Foreign Affairs Review. 2011, (3), p. 46

[2] Among them, China increased its capital to 43 billion U.S. dollars, Russia, India and Brazil each increased their capital by 10 billion U.S. dollars while South Africa added 2 billion U.S. dollars.

[3] F. Wang. BRICS Financial Cooperation in the Perspective of Global Public Goods. The New Finance. $2017,(1)$, p. 26

[4] http://www.pbc.gov.cn/huobizhengceersi/214481/214511/214541/2967384/2016072010054297 624.pdf。

[5] Y. Q. Lin. The Deepening of Financial Cooperation and the Rise of Emerging Countries, Based on a View of the BRICS countries. Chief Editor of BRICS Research Center of Fudan University, BRICS Cooperation and Global Governance Collaborative Innovation Center. International Governance and BRICS Governance Options: Annual Report on BRICS Cooperation and Global Governance (2016), Shanghai People's Publishing House, 2016 p.46

[6] J. Ma. Green finance: China and the G20. Overseas Investment and Export Credit,2016 (6), p.3 